\title{
FÖLDRENGÉSSZÁMÍTÁSI KÉRDÉSEK
}

\section{SEISMIC DESIGN ISSUES}

\author{
Kopenetz Lajos György, ${ }^{1}$ Máthé Alíz Éva, ${ }^{2}$ Gobesz Ferdinánd-Zsongor ${ }^{3}$ \\ Kolozsvári Müszaki Egyetem, Építőmérnöki Kar, Kolozsvár, Románia \\ ${ }^{1}$ ludovic.kopenetz@mecon.utcluj.ro \\ 2 aliz.mathe@mecon.utcluj.ro \\ ${ }^{3}$ go@mecon.utcluj.ro
}

\begin{abstract}
A significant part of our earth falls into an earthquake zone, therefore, when planning and designing residential areas, factories, or other human establishments, professionals take into account the seismic hazard of that area as well. The current earthquake standard in Romania is based on the European code. The paper presents beside the most significant structural composition rules the applicable methods that can be used to ensure the load bearing requirements.
\end{abstract}

Keywords: earthquake, load, bearing structure.

\section{Összefoglalás}

Földünk jelentős része földrengéses zónába esik, ezért a lakótelepek, üzemek, általában az emberi létesítmények elhelyezésénél és tervezésénél a szakemberek figyelembe veszik az illető terület földrengés-veszélyeztetettségi fokát is. A Romániában jelenleg érvénybe lévő földrengés szabvány az európai földrengés szabványra támaszkodik. A dolgozatban bemutatásra kerülnek a fontosabb szerkesztési szabályok mellett a teherbírási követelmények biztosítására alkalmazható módszerek.

Kulcsszavak: földrengés, teher, tartószerkezet.

\section{Bevezetés}

A földrengés az egyik legpusztítóbb természeti csapás, nagy veszélyt jelent az építmények és az emberek épségére. A pusztítás mértékét az eltört gázcsövek és elszakadt villamos vezetékek miatt keletkező tűz is fokozhatja, s amennyiben a víznyomó vezetékek is károsulnak a gyors oltás lehetetlenné válik.

Mivel földünk nagy része földrengéses zónába esik, az emberi települések pedig egyre jobban terjednek, az emberi létesítmények elhelyezésénél és tervezésénél a szakemberek figyelembe veszik az illető terület földrengés-veszélyeztetettségi fokát is. Ahhoz, hogy az épületek tervezésekor majd kivitelezésekor figyelembe lehessen venni a földrengésveszélyt, ismerni kell magát a hatást, valamint annak összes jellemzőit.

\section{Földrengés}

Ismeretes, hogy Földünk több rétegből tevődik össze (földkéreg, felső és alsó köpeny, valamint külső és belső mag), a földrengések a körülbelül 60 kilométer vastagságú földkéregben játszódnak le. Földünk állandó működése következtében mind a felszín feletti, mind a felszín alatti erők feszültségeket hoznak létre, melyek a felszín emelkedésének, süllyedésének, gyürődésének formájában nyilvánulnak meg. A földrengést a feszültségek, vagy felhalmozódott energiák hirtelen felszabadulása okozza. Az energia felszabadulásának leggyakoribb oka a szilárd kéreg törése (ú.n. tektonikus törés). A tektonikus földrengés keletkezését (a feszültségek halmozódása következtében) a kőzetekben fellépő lassú deformáció növekedés előzi meg. Ha a rugalmas feszültségek, 
amelyek a deformáció növekedéssel fokozatosan nagyobbak lesznek, túllépik a kőzetszilárdságot, akkor a rugalmas deformáció potenciális energiájának egy része hirtelen kinetikus energiába megy át, azaz földrengés keletkezik.

A felszabadult mozgási energia a földrengésfészek kis körzetén túl rugalmas hullámok alakjában terjed, melyek alaphullámai a hipocentrumból indulnak ki és a szilárd kéregben mint longitudinális és transzverzális hullámok terjednek. $\mathrm{Az}$ epicentrumból indulnak ki a Love-Reyleigh féle felszíni hullámok. Ezek az előbbi típusok kombinációi, amelyek különböző fizikai jelenségek (interferencia, visszaverődés, rétegek inhomogenitása miatti változás) következtében teljesen szabálytalanok. Tulajdonképpen ezek a hullámok jelentik a közvetlen veszélyt a felszínen levő építményekre.

A régebbi törekvésekkel szemben, melyek a felszíni mozgást matematikai formulákkal igyekeztek megközelíteni, a jelenlegi álláspont az, hogy a felszíni mozgásokat szabálytalan impulzusoknak kell tekinteni, amelyek szabálytalan időközökben követik egymást (az ilyen jellegü hatást tranziens jelenségnek nevezik). Ebből következik az építészetre nézve nagy jelentőségű megállapítás: a hullámok által érintett szerkezetek nem kényszerrezgést végeznek, hanem szabálytalan időközönként megzavart szabad lengést. A nagy eltérés a periodikus hatásokhoz képest az, hogy igen kis valószínűsége van a rezonancia meg a fáradás megjelenésének.

A földrengések mérésének két módját használják. A mérnöki szeizmológia a földrengés-erősségi skálákat használja, míg a geofizikusok a rengés fészkében felszabadult energiát mérik. A földrengés-erősségi skálák kidolgozására a XVIII. század végén és a XIX. században került sor. Minden földrengés-erősségi skálában a rengés által létrehozott, általánosított ismertető jeleket használják. Ezek közül a legfontosabb az épületek sérülési foka meg a talajon létrehozott maradandó jelenségek. Jelenleg a mérnöki szeizmológia a rengés erősségének meghatározására leggyakrabban az MSC-64 (Mercalli-Sieberg-Cancani) skálát alkalmazza [1].

Az MSC-64 skálának, mely a felszíni mozgások, gyorsulások alapján létrehozott változásokkal értelmezi a rengés erősségét, 12 fokozata van. A VI-nál gyengébb erősségű rengések a szakszerűen tervezett és megfelelően kivitelezett épületekre nem jelentenek veszélyt. A IX-nél erősebb rengések elleni védelemre, a jelenlegi építőanyagokat és szerkezeti rendszereket figyelembe véve, nincsen reális lehetőség, ugyanis a vízszintes gyorsulások túlságosan nagyok (az 1963-as szkopjei földrengés a város belső területén VIII-IX erősségű volt [2]).

\section{Tervezési kérdések}

Volt idő, amikor sok építész nem vette komolyan ezt a természeti jelenséget és hiábavaló kiadásnak tartotta a földrengések elleni védekezést. Az ilyen álláspontokat az időközben lezajlott természeti katasztrófák cáfolják. A védekezés költségei lényegesen alacsonyabbak lettek volna mint azt a kezdetben gondolták (a többletkiadás nem haladta volna meg a 7 százalékot). A gyengébb földrengések elleni legegyszerübb védekezés a jó szerkezettervezés és kivitelezés, ami nemhogy többletköltséget jelentene, ellenkezőleg, általa még megtakarítás is elérhető.

Bár a földrengésmozgások több irányúak, szokványos tervezéskor általában csak a vízszintesen ható erőket veszik figyelembe [3].

Az eddigi kutatások szerint földrengéskor azok az épületszerkezetek viselkednek kielégítően, amelyeknek (helyválasztással és szerkezettervezéssel) dinamikus és tömegjellemzőit úgy vették fel, hogy a keletkező szeizmikus erők minél kisebbek legyenek, nem pedig azok, amelyeket az egyébként rosszul megválasztott szerkezeti rendszer túlméretezésével építettek [4]. A szeizmikus erőket lökésszerű dinamikus hatásként kell felfogni és az ebből származó igénybevételt a dinamika módszereivel meghatározni, vagyis nem elegendő a statikus terhelések biztonsági tényezőkkel való növelése. A tervezésnél nagy jelentőségű az altalaji viszonyok figyelembevétele, mivel a felszíni hullámok jellemzői elsősorban ezektől függenek. A szilárd, kötött talajokban lényegesen nagyobbak a súrlódási veszteségek, mint a laza szerkezetű talajokban. Változik továbbá a talajok saját lengésfrekvenciája is. A szilárd talajoké lényegesen magasabb, mint a laza szerkezetüeké, ezért a laza talajokban kedvezőbb helyzetben vannak a nagy saját lengésszámú, merev építmények, míg a szilárd talajokban az alacsony saját lengésszámú rugalmas építmények.

A szeizmikus erők számítására többféle módszer van. Tekintettel a számítások bonyolult voltára, igen nagy jelentőségű a számítógépek alkalmazása és a modellkísérletek bevezetése.

A fontosabb „szerkesztési” szabályok a következők:

Az épület alaprajza minél közelebb álljon a négyzethez (ideális esetben a körhöz) és kiugró szárnyak, épületrészek nem kívánatosak.

Feltétlen legyen szimmetrikus, lehetőleg mindkét irányban. Az épület tömegének súlypontja essék egybe a merevítő elemek súlypontjával. 
A merevítő falak, elemek, minél egyformábbak legyenek. A földszint kétirányú kellő merevsége igen fontos. Az 1974-es bukaresti földrengésnél szinte kizárólag azok a belvárosi épületek omlottak össze, melyeknél a földszintet üzletek céljaira kiváltották és a kiszedett merevítések kellő pótlását elmulasztották. Fontos még egy felső koszorú alkalmazása.

Könnyíteni kell a szerkezet saját súlyát, elkerülni a gyenge csomópontokat és elemeket.

Nagyon kell ügyelni a merevség arányában való gondolkozásnál. A földrengéseknél ez nagyon veszélyes, mert például ha az autó négy kerékrugójából egyet kicserélünk egy 3-szor gyengébbre, rögtön meglátszik mit művel a kocsi...

Más szerkezeti megoldásokkal összehasonlítva, földrengések esetében (a helyes építkezési eljárás mellett) az acélvázas építkezési mód a legellenállóbb, bár az acélszerkezetek igen gyengék a tűzzel szemben.

Olyan hatalmas földrengésnél is, mint amilyen az 1923-as tokiói földrengés volt (Richter skálán: 8,3), az acélszerkezetek viszonylag kis károsodást szenvedtek [5]. A rengésbiztonságot fokozza a szerkezet hajlékonysága, ami nagyobb energiaelnyelést biztosít más szerkezetekhez képest. A tapasztalatok szerint az acélszerkezet tízszer nagyobb deformációt visel el, mint egy vasbetonszerkezet. Mind a vasbeton, mind az acélszerkezeteknél az a kedvező, ha az épület egészében egységes a merevség, mert például a hajlékony födémek az alakváltozás különbözősége következtében nagy torzulásokat szenvedhetnek. Ezért a tervezők ugyanazon a szinten az oszlopokat és tartógerendákat egyenlő merevségüre tervezik, s csak fokozatosan változtatják emeletről emeletre. A vasbeton szerkezetek közül azok bizonyultak a legellenállóbbaknak, amelyeket monolit technológiával építettek. Nagypaneles vasbeton szerkezeteknél azok a megoldások előnyösebbek a rengésekkel szemben, amelyeknél minél kevesebb a hézag, azaz minél nagyobb panelekből állnak és a hézagoknál a panelek kapcsolatát a legbiztonságosabban oldják meg.

Az eddigi eredmények tehát amellett szólnak, hogy még a leghevesebb földrengések ellen is van reális lehetőség a védekezésre.

\section{Földrengésszámítási kérdések}

A jelenleg érvénybe lévő romániai földrengés szabvány [6] az európai EC8 (EN 1998-1) földrengés szabványra támaszkodik, de meghaladja ezt. Míg az EC8 150 éves átlag visszatérési interval- lumot vesz figyelembe a földrengés méretére, a P100-1 225 évest ír elő (hosszabb időtartam alatt nagyobb földrengés jelnetkezhet). Egy másik lényeges különbség, hogy míg az EC8-ban két duktilitási osztály van (magas és közepes), a P100-1ben egy harmadik is be lett vezetve (alacsony). Ezek a szabványok szigorú követelményeket tartalmaznak:

- végrehajtási követelmények (performance requirements);

- teljesítési kritériumok (compliance criteria);

-teherbírási vagy lábon maradási követelmény (no-collapse requirement);

-alakváltozási követelmények (damage limitation requirements).

A szerkezettervező a teherbírási követelmények biztosítására a következő módszereket alkalmazhatja:

- a vízszintes ekvivalens erő módszerét (lateral force method) amely az épületre ható vízszintes dinamikus erőket egyenértékű statikus erőkkel helyettesíti;

- válaszspektrum analízis (modal response spectrum analysis);

-nemlineáris statikus vagy eltolódás módszere (push over analysis);

- nemlineáris dinamikai vagy teher történeti (time-history) analízis;

- probabilisztikus módszer.

Jelenleg a tervezésben az első két módszert használják gyakrabban.

A földrengés hatása az épületre tulajdonképpen egy tehetetlenségi erő (F), vagyis az épület tömege (m) és a szerkezetbe indukált mozgás gyorsulásának (a) szorzata (Newton törvény - 1687):

$$
F=-m \cdot a
$$

Eképp nyilvánvaló, hogy a szerkezeti gyorsulás a földrengés által indukált maximális vízszintes talajgyorsulás $\left(a_{g}\right)$ függvénye. Az $a_{g}$ a viszonylagos gyorsulás $\left(k_{s}\right)$ és nehézségi gyorsulás szorzata:

$a_{g}=k_{s} \cdot g$

$\mathrm{Az}$ abszolut gyorsulások rugalmas válaszspektrumát vízszintes talajmozgásra (m/ $/ \mathrm{s}^{2}$-ben) a következőképp lehet meghatározni:

$$
S_{e}(T)=a_{g} \cdot \beta(T)
$$

A szerkezeti gyorsulást a talaj gyorsulásából kapjuk a válaszspektrumok alapján. A válaszspektrum görbék függnek:

- a talajosztálytól, vagyis a talajmozgás saját periódusától ( $\left.T_{C}\right)$ (1. ábra és 1. táblázat);

- a szerkezet dinamikai tulajdonságaitól (merevség, tömegeloszlás, sajátrezgés periódusai, szerkezeti csillapítási tényezők).

A normalizált vízszintes talajgyorsulás rugalmas $\beta(T)$ válaszspektrumát, $\xi=0,05$ kritikus csil- 
lapítás konvencionális értékére az alábbi képletek adják az ellenőrzési periódusok $\left(T_{B}, T_{C}, T_{\mathrm{D}}\right)$ függvényében:

$$
\begin{array}{ll}
T_{C} \leq T_{B} & \beta(T)=1+\frac{\left(\beta_{0}-1\right)}{T_{B}} \cdot T \\
T_{B}<T \leq T_{C} & \beta(T)=\beta_{0} \\
T_{C}<T \leq T_{D} & \beta(T)=\beta_{0} \cdot \frac{T_{C}}{T} \\
T>T_{D} & \beta(T)=\beta_{0} \cdot \frac{T_{C} \cdot T_{D}}{T^{2}}
\end{array}
$$

A fenti képletekben T a lengési periódusa egy 1 dinamikai szabadságfokkal rendelkező rugalmas szerkezetnek, míg $\beta_{0}$ a talaj vízszintes gyorsulásának a dinamikus növelési együtthatója $\left(\beta_{0}=2,5\right)$. A $T_{C}$ sarokperiódus az abszolut gyorsulások és relatív sebességek spektrumai közti határt jelenti és másodpercben mérik. A $T_{B}$ egyszerüsítve számítható $\left(T_{B}=0,2 \cdot T_{C}\right)$, míg a $T_{D}$ a maximális relatív sebességek és a relatív elmozdulások spektrumai közti határt jelenti.

Mivel a szerkezettervezés és méretezés során a szerkezet a rugalmas-képlékeny tartományban dolgozik, a tervezési normalizált válaszspektrumot a $q$ viselkedési tényező bevezetésével kapjuk. Így a tervezési szerkezeti gyorsulás spektruma a következő függvényekkel írható le:

$$
\begin{aligned}
& 0<T \leq T_{B} \quad S_{d}(T)=a_{g} \cdot\left[1+\frac{\frac{\beta_{0}}{q}-1}{T_{B}} \cdot T\right\rceil \\
& T>T_{B} \quad S_{d}(T)=a_{g} \cdot \frac{\beta(T)}{q}
\end{aligned}
$$

Közelítő számításként használható a vízszintes erő módszere, ha a rezgésidők jól szeparáltak (vagyis nem kapcsolt rezgések) és az alap periódus: $T<1,6$ s.

Az alap nyíró erő értékét a következő képlet adja:

$$
F_{b}=\gamma_{I} \cdot S_{d}\left(T_{1}\right) \cdot m \cdot \lambda
$$

ahol $S_{d}\left(T_{1}\right)$ a tervezési szerkezeti gyorsulás spektruma az alap periódusnál (vagy alap rezgésidőnél) [m/s²]; $T_{1}$ az alap rezgésidő (periódus) [s]; $\gamma_{I}$ az épület fontossági osztálya $\left(\gamma_{I}=0,8 \ldots 1,4\right) ; \mathrm{m}$ az épület tömege; $\lambda$ módosító tényező (ha $T_{1}<T_{C}$ és ha az épületnek több mint két szintje van, akkor 0,85 ; egyébként 1,0 ).

Az alap rezgésidőt több módszerrel lehet becsülni, például:

$$
T_{1}=C_{t} \cdot H^{3 / 4}
$$

ahol $H$ az épület magassága (a befogástól számítva) [m], míg a $C_{t}$ értéke acélszerkezeteknél 0,085 ; vasbetonszerkezet, illetve centrikusan merevített acélszerkezet esetében 0,075; a többi esetben 0,050.

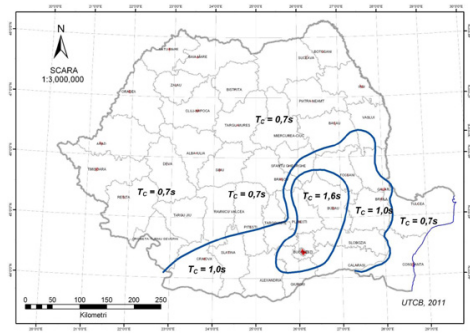

1. ábra. Románia területi tagolása a $T_{c}$ ellenőrzési periódus szerint [6].

1. táblázat. $\mathrm{A} T_{B}, T_{C}$ és $T_{D}$ ellenőrzési periódusok értékei a vizszintes földmozgáshoz [6]

\begin{tabular}{|l|l|l|l|}
\hline $\boldsymbol{T}_{\boldsymbol{C}}$ & $0,70 \mathrm{~s}$ & $1,00 \mathrm{~s}$ & $1,60 \mathrm{~s}$ \\
\hline $\boldsymbol{T}_{\boldsymbol{B}}$ & $0,14 \mathrm{~s}$ & $0,20 \mathrm{~s}$ & $0,32 \mathrm{~s}$ \\
\hline $\boldsymbol{T}_{\boldsymbol{D}}$ & $3,00 \mathrm{~s}$ & $3,00 \mathrm{~s}$ & $2,00 \mathrm{~s}$ \\
\hline
\end{tabular}

\section{Következtetések}

A mai tartószerkezettervezés elképzelhetetlen földrengési védelem nélkül. A szabványok fejlődése a biztonság növelése irányában halad. A szerkezetek részletesebb nemlineáris vizsgálata időigényes és költséges lehet bonyolult nagy építmények esetében és komolyabb számítástechnikai felszerelést igényel. Amennyiben a tervező mérnök tisztában van a földrengés jelenségével és ennek az épületre gyakorolt hatásával, egyszerűsített eljárásokkal és helyes szerkezeti kialakítással is megfelelő biztonságot tud elérni.

\section{Szakirodalmi hivatkozások}

[1] Musson R. M. W., Grünthal G., Stucchi M.: The comparison of macroseismic intensityscales. Journal of Seismology, Springer Verlag, 14/2. (2009) 413-428.

[2] Suhadolc P., Sandron D., Fitzko F., Costa G.,: Seismic ground motion estimates for the M6.1 earthquake of July 26, 1963 at Skopje, Republic of Macedonia, Acta Geodaetica et Geophysica Hungarica, 39/2-3. spec. iss. (2004) 319-326,

https://doi.org/10.1556/AGeod.39.2004.2-3.13

[3] Kopenetz L. Gy.: Gondolatok statikusoknak. Kriterion Könyvkiadó, Kolozsvár, 2006.

[4] Kegyes-Brassay O., Ray R. P.: Earthquake Risk Assessment - Effect of a Seismic Event in a Moderate Seismic Area, Acta Technica Jaurensis, 9/1. (2016) 1-15.

[5] de Boer J. Z., Sanders D. Th.: Earthquakes in human history: the far-reaching effects of seismic disruptions., Princeton University Press, Princeton, New Jersey, 2005, pp.278.

[6] P100-1: Cod de proiectare seismică. Partea I - prevederi de proiectare pentru cladiri, MDRAP, 2013. 